\title{
POROČILO O ZASEDANJU KOMISIJE ZA SLOVNIČNO ZGRADBO SLOVANSKIH JEZIKOV PRI MEDNARODNEM SLAVISTIČNEM KOMITEJU (LJUBLJANA, 4.-6. SEPTEMBER 2014)
}

\section{Robert GROŠELJ}

Filozofska fakulteta Univerze v Ljubljani

Grošelj, R. (2014): Poročilo o zasedanju Komisije za slovnično zgradbo slovanskih jezikov pri Mednarodnem slavističnem komiteju (Ljubljana, 4.-6. september 2014). Slovenščina 2.o, 2 (1): $67-75$.

URL: http://www.trojina.org/slovenscina2.o/arhiv/2014/1/Slo2.o_2014_1_o5.pdf.

Med 4. in 6. septembrom 2014 je na Filozofski fakulteti Univerze v Ljubljani potekalo zasedanje Komisije za slovnično zgradbo slovanskih jezikov pri Mednarodnem slavističnem komiteju, ki ga je organizirala in vodila red. prof. dr. Andreja Žele, tudi članica omenjene komisije (krovna organizatorja sta bila - v okviru Filozofske fakultete UL - oddelka za slovenistiko in slavistiko). Ker gre za pomembno srečanje uglednih slavističnih jezikoslovcev, je treba opozoriti na njegov znanstveni jezikoslovni prispevek.

Na zasedanju je svoje prispevke predstavilo 21 jezikoslovcev (velika večina iz Evrope), ki so večinoma v ruščini razpravljali o posameznih glagolskih oblikah, vezljivosti, o neglagolski besednovrstni problematiki (največji sklopi), stavčni skladnji, o arealnolingvističnih vprašanjih in možnostih leksikografskega oz. slovničnega opisa. Referati so posegali na različna slovnična področja, nekatera za slovenščino tudi slabo raziskana, zato velja omeniti vsaj vsebinske poudarke prispevkov. ${ }^{1}$

Na področje glagolskih oblik so sodili prispevki A. Barentsena (Nizozemska),

\footnotetext{
1 Prim. tudi zbornik razširjenih povzetkov: ŽELE, Andreja (ur.): Zasedanje Komisije za slovnično zgradbo slovanskih jezikov pri Mednarodnem slavističnem komiteju, Ljubljana, 4.6. septembra 2014. Ljubljana: Znanstvena založba Filozofske fakultete, 2014. 73 str. - Ker zaradi službenih obveznosti nisem mogel poslušati referatov V. S. Hrakovskega in I. M. Boguslavskega, navajam poudarke po zborniku povzetkov.
} 
T. Bergerja (Nemčija), R. Nicolove (Bolgarija), M. Nomachija (Japonska), L. Popović (Srbija), J. Nørgårda-Sørensena (Danska), H. Tommola (Finska) in V. S. Hrakovskega (Rusija). A. Barentsen je predstavil preliminarno raziskavo rabe predpreteklika $\mathrm{v}$ slovanskih jezikih (tudi primerjalno $\mathrm{z}$ neslovanskimi jeziki), ki temelji predvsem na gradivu prevodov Malega princa. - T. Berger je obravnaval performative $\mathrm{v}$ češčini in slovaščini $\mathrm{v}$ primerjavi $\mathrm{z}$ ruščino. Po morfoloških, skladenjskih in pomenskih značilnostih performativi v teh jezikih sovpadajo, razlike pa se pojavljajo v odvisnosti od naklonskih izrazov (zaradi različne rabe glede na pragmatični cilj). $\mathrm{V}$ vseh treh jezikih se performativi lahko pojavljajo $\mathrm{v}$ dov. vidu (v zahodnoslovanskih jezikih pogosteje), razlike med jeziki pa so povezane $\mathrm{z}$ večpomenskostjo posameznih glagolov. - M. Nomachi je pri razlagi kašubske oblike preteklika jô bët 'jaz (sem) bil’ nam. (jô) jem bët '(jaz) sem bil' razmišljal o možnosti, da gre za morebitni nemški vpliv (ne opušča osebkov) ali notranjejezikovni razvoj, podoben ruskemu ja Ø byl, prim. starorusko (ja) esmb bylz. Avtor je opozoril še na tri spregledane dinamične vidike razvoja: tipološko non-pro-drop tendenco, tendenco opuščanja sedanjiških oblik pomožnega glagola bëc 'biti' in diahrono razmerje med njima. Pri tovrstnih razvojih bi bilo treba izpostaviti tudi možnost delovanja tako notranjejezikovnega razvoja kot tujejezikovnega vpliva. - R. Nicolova je predstavila bolgarski posesivni perfekt in eksistencialni trpnik $\mathrm{s}$ habere. Poleg polno gramatikaliziranega glagola $\mathrm{v}$ zanikanih oblikah prihodnjikov obstajata $\mathrm{v}$ bolgarščini še dve zgradbi z delno gramatikalizacijo: posesivni perfekt имам + pret. trpni del. + sam. (Имам една написана статия. 'Imam napisano eno razpravo.') in eksistencialni trpnik uмa brezos. + pret. trpni del. + sam. (Има написана статия по този въпрос. 'Obstaja/je napisana razprava o tem vprašanju.'). Bolgarski posesivni perfekt je, tako kot v drugih slovanskih jezikih, na začetni stopnji gramatikalizacije (zaradi vrste slovničnih in pomenskih omejitev). Pri eksistencialnem trpniku pa je avtorica izpostavila omejitve v primerjavi s pravim trpnikom (razlike v informacijski zgradbi in determinaciji predmetnega sam.). Avtorica žal ni problematizirala 
posebnega stanja v knjižni makedonščini - L. Popović se je ukvarjala z evidencialnimi pomeni srbskih preteklih časov in ugotovila, da se aorist primarno uporablja za posredovanje informacije $\mathrm{z}$ vidika neposrednega opazovalca, perfekt pa zaradi širitve rabe postopoma postaja nezaznamovani pretekli čas (kar pomeni približevanje stanju v drugih slovanskih jezikih). Avtorica je hkrati opozorila, da okrnjeni perfekt privzema tipično aoristovo rabo (opis dejanja z vidika opazovalca): Stigli gosti. - Stigoše gosti. (npr. v časopisnih naslovih, biografijah, poročilih o izvršenem dejanju). - J. NørgårdSørensen je problematiziral staroruski sistem preteklih časov, in sicer v luči postopnega razvoja iz pozno praslovanskega sistema (z več časi) v sodobni ruski sistem (s preteklikom iz perfekta). Avtor meni, da je treba za boljše razumevanje časov raziskati paradigmatska razmerja med njimi, hkrati pa domneva, da so imeli govorci že v stari ruščini na razpolago tudi »sodobni « časovni sistem (z le enim preteklim časom). - H. Tommola se je posvetil - tipološko - ruskemu perfektu, ki je z izginotjem ostalih preteklih časov postal univerzalni pretekli čas. Ob invariantnem pomenu aktualne relevantnosti Tommola pri perfektu navaja še štiri posebne pomene, prim. rezultativni perfekt, perfekt nedavnega dejanja, eksperiencialni in inkluzivni perfekt. Avtor ugotavlja, da se v vrsti jezikov eksperiencialnost in inkluzivnost izražata z neperfekti, poleg tega pa lahko v vlogi kazalca perfektnega pomena nastopa tudi prislov s pomenom ‘že'. - V. S. Hrakovskij je predstavil reinterpretacijo ponavljalnih pomenov nedovršnega vida $\mathrm{v}$ ruščini. Osnovni pomen ruskega nedovršnika naj bi bila nespremenljivost - situacija, ki jo označuje nedovršni glagol, v določenem časovnem intervalu ostaja identična. Ponavljalnost ni del gramema nedovršnosti, temveč se izraža s sobesedilnimi sredstvi, pri čemer avtor loči med multiplikativno (v enem časovnem intervalu; izraža se leksemsko, npr. Živčno je zeval, pogledoval sosede ...) in iterativno ponavljalnostjo (vsako ponovljeno situacijo zaznamuje poseben časovni interval; izraža se z ustreznim kontekstom, prim. Običajno je prihajala pod večer.). V omenjenih primerih ponavljalni pomen kompozicijsko sodeluje z gramemom nedovršnosti, ki mu je 
lastna tudi neprogresivnost, ta pa se sicer lepo sklada s progresivnostjo. Progresivnost in neprogresivnost se kažeta kot varianti nespremenljivosti kot osnovnega pomena gramema nedovršnosti.

Kot vezljivostne bi lahko označili prispevke I. M. Boguslavskega (Rusija), L. L. Iomdina (Rusija), B. Normana (Belorusija) in K. Skwarske (Češka).

I. M. Boguslavskij se je v prispevku lotil pomena ruskih parcialnih izrazov (označujejo del celote) in njihovega razmerja do drugih elementov povedi. Parcialni sam. predvidevajo udeleženca celote ali dela (oba v rod.), parcialni prisl. izrazi pa se lahko pojavljajo v kontekstih mejne situacije (npr. zgraditi hišo 8o-odstotno) in primerjave (npr. proizvodnjo povečati za četrtino). V pomenu 'več' (prim. težje od, lažje od) se predlaga dvodoločilna zgradba, medtem ko je količina povečanja dopolnilo. Avtor opozarja še na glagol разбавлять 'redčiti' (npr. mleko z vodo), ki se zdi povečevalen (tj. 'dodajati vodo'), čeprav se obnaša kot pomanjševalen, ter na razlike med predpono nолy'pol-' ter prislovom наполовину 'napol'. - L. L. Iomdin je obravnaval vezljivost ruskih predikativnih izrazov $\mathrm{v}$ nekaj mikroskladenjskih zgradbah eksistencialnega tipa (npr. кому-л. нет нужды делать что-л. 'komu ni treba delati česa'). $V$ teh zgradbah naj se ne bi dalo opredeliti (glede na vezljivost samih izrazov), katere udeleženske položaje zasedajo (predložno)sklonska določila, saj naj bi se udeleženci oddaljevali od nosilcev vezljivosti in stremeli k prototipičnemu pomenu predloga ali sklona (poleg tega pri določilih prihaja še do močne variantnosti). Vezljivost takšnih izrazov mora biti zato natančno opisana v slovarju. Iomdin ugotovlja, da je v sodobni ruščini (v primerjavi z začetkom 20. stol.) dajalniško določilo (z osebkovo vlogo) nadomestila predložna zveza $u+$ rod. $\mathrm{K}$ prispevku bi lahko dodali, da je nenapovedljivost vezljivosti ( $\mathrm{v}$ teh primerih) glede na izhodiščni vezljivostni model morda posledica pomenske raznolikosti homonimnih leksemov. - B. Norman je pri vezljivostni realizaciji glagola brez določil izpostavil štiri situacije: slovarsko geslo (pogosto brez vezljivostnih podatkov); stopnja obveznosti udeležencev (glede na referenčno situacijo - poudarek na sami dejavnosti); splošna 
referenca ( $\mathrm{v}$ pregovorih, aforizmih itn.) kot 'obrazec obnašanja'; priredna razmerja, ko glagol tudi vezljivostno podpirajo sosednji glagoli. - K. Skwarska je analizirala posebno izražanje udeležencev situacije pri glagolih rekanja $\mathrm{v}$ češčini, ruščini in poljšćini. Vsebinski udeleženec je namreč lahko realiziran v dveh določilih ali enem - gre za t. i. razpad teme in diktuma, prim. Pripovedoval je, da je brat odpotoval. - Pripovedoval je o bratu, da je odpotoval. Avtorica je spregovorila o oblikoslovni in skladenjski realizaciji določil teh glagolov (prim. prednostno mluví o něčem proti řiká, že ...) ter o možnosti njihove leksikografske predstavitve.

Z neglagolsko besednourstno problematiko sta se ukvarjali E. V. Padučeva (Rusija) in A. Žele (Slovenija), medtem ko je J. Wajszczuk (Poljska) predstavila možnost skladenjske besednovrstne členitve.

E. V. Padučeva je obravnavala zanikanje ob vezniku пока 'dokler', ki po njenem mnenju ni pleonastično, temveč ohranja svoj pomen, ki izhaja iz sovplivanja med veznikom in vidskimi značilnostmi besedila. Avtorica izpostavlja razliko med mоžnostma $S_{1}$ пока не- $S_{2}$ 'situacija $S_{1}$ poteka sočasno z neuresničitvijo $S_{2}$ ' $\rightarrow \mathrm{S} 1$ se zgodi tedaj, ko traja stanje neuresničitve $\mathrm{S} 2$ (пока $\mathrm{v}$ sobesedilu dov. glagola z zanikanjem) in $S_{1}$ пока $S_{2}$ 'situacija $S 1$ je sočasna s perfektivnim stanjem S2' (dov. glagol, razmerje med situacijama je časovno), prim. Смотри, пока не погасло. (pribl. 'Glej, dokler ni ugasnjeno.') in Смотри, пока погасло. (pribl. 'Glej, dokler je ugasnjeno.'). - A. Žele je pri slovenskih členkih opozorila na njihovo besedilno funkcijo - gre za funkcijsko besedo (slovarske razlage so le funkcijske), ki pomensko niansira sledečo določevano (polnopomensko) besedo; členek kot zgoščeni ubesedeni govorni dogodek opozarja tudi na spremenjene okoliščine besedila. S pragmatičnega vidika avtorica členke deli na povezovalne (poudarek na besedilnih razmerjih), ki se funkcijsko približujejo veznikom, in naklonske (poudarek na medosebnih razmerjih), pri katerih stopajo v ospredje razodevalna, pozivna in stikovna besedilna vloga. Ta funkcijska besedna vrsta $\mathrm{s}$ pomenskorazmerno vlogo aktualizira ubesedeno in besedilo tudi sporočilno zgošča. - Besednovrstno 
problematiko je predstavila tudi J. Wajszczuk. S skladenjskim (sintagmatskim) kriterijem avtorica leksiko členi na dva osnovna razreda, lekseme (zaznamuje jih široko pojmovana kombinabilnost, tj. odpirajo mesto za vsaj eno leksikalno enoto) in paralekseme (t. i. kvazi-besede, npr. medmete, klice, ki jim manjka polna notranja pomenska zgradba). Leksemi se v nadaljevanju členijo na sintakteme, ki odpirajo ali zasedajo pomensko določena mesta, in paratakteme (vezniki, členki), ki so zgolj metabesedilni operatorji (ne zasedajo in ne odpirajo pomensko določenih mest). Sintaktemi se v nadaljevanju delijo na prave sintakteme, ki odpirajo mesta za določen razred leksemov, in metapredikativne operatorje (intensifikatorji, aproksimatorji, limitatorji), ki se družijo z več razredi leksemov (poljsko bardzo, slovensko zelo).

Stavčni skladnji so posvetili prispevke M. Danielewiczowa (Poljska), J. Panevová (Češka) in B. Wiemer (Nemčija).

M. Danielewiczowa je opredelila zgradbo in pomen poljskih esklamativov. Osnovni zgradbeni tipi esklamativov (predvsem t. i. wh-exclamations tipa Jak schudłeś! Kako si shujšal!) so predstavljeni kot zgradbe, ki sodijo v skladenjsko ravnino jezikovnega sistema, so specializirane za esklamativno funkcijo, imajo posebno prozodijo in pomenske lastnosti. Avtorica utemeljuje njihov posebni povedni status (ob pripovednih, vprašalnih in velelnih povedih) na osnovi njihove pomenske dimenzije, saj gre za vrsto ignorativov, ki izražajo napetost med védenjem govorca o neki temi in nesposobnostjo verbalizacije védenja. Čustvenost esklamativov pa je vezana na njihovo zgradbo (predvsem prozodično) in ima pragmatičen značaj. - J. Panevová je analizirala razmerje med ujemalnim izglagolskim prid. prilastkom in oziralnim odvisnikom, ki veljata za skladenjska sinonima (izločeni so izglagolski pridevniki, ki so se leksikalno osamosvojili). Med oblikoslovnimi in skladenjskimi pogoji (omejitvami) za kondenzacijo odvisnika so funkcija koreferenčnega elementa v nekondenziranem odvisniku, časovna razmerja med povedkoma in kompleksnost pridevniške zveze. - B. Wiemer se je posvetil nedoločnikom kot samostojnim povedkom in ekvivalentnim načinom izražanja nefaktivnosti $\mathrm{v}$ 
ruščini, poljščini in balkanskoslovanskih jezikih. Avtor ugotavlja najprej razlike v rabi nedoločnika med jeziki (raba nedoločnika v ruščini je bolj raznovrstna kot v poljščini, medtem ko v makedonščini nedoločnika ni), nato pa ugotavlja, da se pogosto na mestu nefaktivnih nedoločnikov (prim. rusko Сидеть тихо u молчать! 'Tiho sedi in molči!') uporabljajo tudi zgradbe s funkcijskimi besedami (rusko как бы, poljsko jakoby, makedonsko да), ki jih je treba upoštevati v tipologiji tovrstnih stavčnih zgradb.

J. D. Apresjan (Rusija) se je v leksikografsko usmerjenem prispevku o sovplivanju leksike in slovnice zavzel za kompleksen aktivni slovar (ruski nastaja na Inštitutu za ruski jezik RAN v Moskvi) z natančnimi opisi (ustrezajo besedilotvorni funkciji). Svoje poglede je ponazoril z glagolom видеть (13 leksemov), izpostavil pa je leksem видеть 'biti gledalec' (prim. slovensko Tega filma še nismo videli.). Slovarski opis leksema, ki ga ne navaja noben razlagalni slovar ruskega jezika, vsebuje slovnične podatke (ni dov.), primere, pomen s komentarjem (raba samo v pret. času; označuje rezultat v dovolj oddaljeni preteklosti, ki ni povezan s trenutkom govorjenja - oboje ga ločuje od sopomenke смотреть 'gledati'), vezljivost (A1 - im., A2 - tož., A3 - kje) z zgledi, sopomenke, analoške glagole (tipa slišati), konverzive (tipa pokazati), tvorjenke. - Na področje gramatikografije bi sodil prispevek M. Grochowskega (Poljska), ki je po tridesetih letih ocenil aktualnost skladenjskega zvezka poljske akademske slovnice (Składnia, 1984) in pogledal v prihodnost poljske skladnje. $\mathrm{V}$ osnovi bi morala nov skladenjski opis sestavljati poglavja o skladnji stavkotvornih (z os. glag. obliko) in nestavkotvornih prvin (predvsem samostalniške in prislovne zveze, ki stavkotvornim prvinam konkurirajo ali pa vstopajo $\mathrm{v}$ njihove vezljivostne položaje), o skladnji operacij sensu largo (pretvorbe, nadomestne zgradbe), o skladnji metaprvin (vezniki, členki, metabesedilni komentarji, tematizatorji tipa à propos, metapredikativni operatorji tipa prawie 'skoraj' itn.) in linearni skladnji (besedni red, prozodija). - H. W. Schaller (Nemčija) je v arealnolingvističnem prispevku opredelil tipološke značilnosti bolgarščine kot balkanskega in evropskega jezika. Tipične 
balkanske značilnosti, kot so odsotnost sklonskih oblik (njihovo nadomeščanje s predložnimi zvezami in besednorednim položajem), kazalni zaimki kot določni členi, izguba nedoločnika, analitično prid. stopnjevanje, tvorba števnikov 11-19 po principu aritmetičnega zlaganja, se pojavljajo tudi v nebalkanskih romanskih, skandinavskih in baltskih jezikih ter evropskih neindoevropskih jezikih, zato Schaller na podlagi evrolingvističnih podmen ocenjuje, da je bolgarščina slovanski, balkanski, a tudi evropski jezik.

A. Barentsen in E. V. Padučeva sta napovedala drugačni temi referatov, medtem ko se J. I. Bjørnflaten (Norveška), I. Kucarov (Bolgarija), E. Petroska (Makedonija) zasedanja niso udeležili.

Na zasedanju komisije so poslušalci imeli priložnost pogledati v jezikoslovno delavnico pomembnih slavistov, ki so opozorili (tudi skozi diskusijo) na različne problemske točke $\mathrm{v}$ slovnični zgradbi slovanskih jezikov in na možnosti njihovega raziskovanja. Obravnave raznovrstnih slovničnih pojavov (v zvezi z glag. oblikami, vezljivostjo, slovničnimi besednimi vrstami, stavčno skladnjo itn.) so bile večinoma sinhrone, enojezikovne in (funkcijsko) strukturalistične, čeprav so nekateri jezikoslovci svoje analize nadgrajevali $\mathrm{z}$ diahronimi, kontrastivnimi, tipološkimi, tudi sociolingvističnimi komentarji itn. (hkrati pa je bilo moč opaziti razlike po nacionalnih jezikoslovnih šolah). Zasedanje komisije je bilo vsekakor izvrstna izkušnja za vse, ki so se ga lahko udeležili (škoda, da ni bilo več podiplomskih študentov - zanje bi bil to odličen podiplomski seminar!), med drugim tudi zato, ker je opozorilo na odprta vprašanja v opisu slovenskega jezika, pokazalo možnosti njihove analize ter, ob kritičnem razmisleku, tudi njihove omejitve. Izboljšavo tovrstnih srečanj bi morda predstavljalo manjše število tematskih blokov (npr. zgolj funkcije preteklih časov v slovanskih jezikih) - v več poglobljenih (kritičnih) razpravah o določeni problematiki ( $\mathrm{v}$ različnih jezikih, z različnih vidikov, z drugačnimi metodami) bi se lahko še bolj izkristalizirala ključna jezikoslovna vprašanja in poti do čim boljših odgovorov. 
To delo je ponujeno pod licenco Creative Commons: Priznanje avtorstvaDeljenje pod enakimi pogoji 2.5 Slovenija.

This work is licensed under the Creative Commons Attribution ShareAlike 2.5 License Slovenia.

http://creativecommons.org/licenses/by-sa/2.5/si/

$$
\text { (c) } \underset{\mathrm{BY}}{\mathrm{B}} \text { (2) }
$$

